\title{
Potentiometric, spectrophotometric, conductimetric and thermodynamic studies on some transition metal complexes derived from 3-methyl-1-phenyl- and 1, 3-diphenyl-4-arylazo-5-pyrazolones
}

\author{
Samir A. Abdel-Latif ${ }^{1 *}$, Saber E. Mansour ${ }^{2}$, Abdulrahman A. Fatouh $^{2}$ \\ 1Chemistry Department, Faculty of Science, Helwan University, Helwan, Egypt; ${ }^{*}$ Corresponding Author: salatif $1 @$ yahoo.com \\ ${ }^{2}$ Chemistry Department, Faculty of Science, Omar Al-Mukhtar University, Al-Beidaa, Libya
}

Received 6 March 2010; revised 23 April 2010; accepted 28 April 2010.

\begin{abstract}
A new 3-methyl-1-phenyl-4-arylazo-5-pyrazolone and 1,3-diphenyl-4-arylazo-5-pyrazolone have been synthesized and characterized by elemental analysis, IR, mass and ${ }^{1} \mathrm{H}$ NMR spectra. The acid dissociation constants ( $\mathrm{pK}_{\mathrm{a}}$ values) of the investigated ligands were determined potentiometrically and spectrophotometrically. The stability constants of the transition metal ions $\left(\mathrm{VO}^{2+}, \mathrm{Cr}^{3+}, \mathrm{Mn}^{2+}, \mathrm{Co}^{2+}, \mathrm{Ni}^{2+}, \mathrm{Cu}^{2+}\right.$ and $\left.\mathrm{Zn}^{2+}\right)$ with the investigated ligands were determined potentiometrically at different ionic strengths $(0.167$, $0.1,0.05$ and $0.025 \mathrm{M}) \mathrm{NaCl}$ at $25^{\circ} \mathrm{C}$ and different temperature $\left(25,30,35\right.$, and $\left.45^{\circ} \mathrm{C}\right)$. The values of stability constants were found to decrease with increasing ionic strengths and temperature. The stoichiometries were studied using spectrophotometric and conductimetric methods, the results indicate the existence of 1:1 and 1:2 (M:L) metal:ligand species. The relationships between the stability constants of the complexes, ionization constants of the ligands have been discussed and correlated. The thermodynamic parameters $(\Delta \mathbf{G}, \Delta \mathbf{H}$ and $\Delta \mathbf{S})$ and the thermodynamic stability constants for all of the investigated complexes were determined potentiometrically.
\end{abstract}

Keywords: Azopyrazolones; Lonization Constants; Stability Constants; Thermodynamic Parameters; Transition Metal Complexes; Potentiometry; Spectrophotometry

\section{INTRODUCTION}

Pyrazolone and azopyrazolone compounds are widely used as analytical reagents, they are capable of form- ing chelates with a number of metal cations [1,2], the formation of which is accompanied by change in color, $\mathrm{pH}$, conductivity, and absorption spectra [3]. Azo derivatives have attracted much attention by virtue of their applicability as potential ligands for a large number of metal ions [1]. The 4-position of pyrazoline-5-one system is highly reactive and undergoes coupling reaction with diazonium salts to give 4-arylazo derivatives [4]. The azo-derivatives of 5-pyrazolones as well as their metal complexes have wide applications in dye industry as well as analytical reagents for determination of trace metals and it is predicted to have some medical and biological applications $[5,6]$. Different methods were reported for the syntheses of azopyrazolone derivatives [7-12].

The present paper deals with the determination of the stability constants of the binary complexes of $\mathrm{VO}^{2+}, \mathrm{Cr}^{3+}, \mathrm{Mn}^{2+}, \mathrm{Co}^{2+}, \mathrm{Ni}^{2+}, \mathrm{Cu}^{2+}$ and $\mathrm{Zn}^{2+}$ metal ions with the investigated ligands (L1-L6) in the presence of $0.167,0.1,0.05$ and $0.025 \mathrm{M}$ at $25^{\circ} \mathrm{C}$. The thermodynamic parameters $(\Delta \mathrm{G}, \Delta \mathrm{H}$ and $\Delta \mathrm{S})$ and the thermodynamic stability constants of the investigated complexes were evaluated in the presence of $0.1 \mathrm{M}$ $\mathrm{NaCl}$ in the temperature range $25-45^{\circ} \mathrm{C}$. The Irving and Rossotti $\mathrm{pH}$-metric titration using Sarin and Munchi technique [13] was used to determine the acid dissociation constants as well as the formation constants for the various complexes at $25^{\circ} \mathrm{C}$. The acid dissociation constants were also done in $40 \%$ ethanolic buffer solutions of varying $\mathrm{pH}$ values spectrophotometrically [14]. The molar ratio of the metal ions to ligands $[\mathrm{M}] /[\mathrm{L}]$ were studied spectrophotometrically using molar-ratio and continuous variation methods and were also determined using conductimetric titrations in aqueous ethanolic solutions $(40 \%$ $\mathrm{v} / \mathrm{v})$. 


\section{EXPERIMENTAL}

\subsection{Materials and Methods}

All chemicals used in this investigation were chemically pure grade derived from $\mathrm{BDH}$. They include chlorides of $\mathrm{Cr}^{3+}, \mathrm{Mn}^{2+}, \mathrm{Co}^{2+}, \mathrm{Ni}^{2+}, \mathrm{Cu}^{2+}, \mathrm{Zn}^{2+}$ and $\mathrm{VOSO}_{4} \cdot 3 \mathrm{H}_{2} \mathrm{O}$, sodium hydroxide $(\mathrm{NaOH})$, sodium nitrite $\left(\mathrm{NaNO}_{2}\right)$, hydrochloric acid $(\mathrm{HCl})$, acetic acid $\left(\mathrm{CH}_{3} \mathrm{COOH}\right)$, sodium chloride $(\mathrm{NaCl})$, ethylacetoacetate, ethylbenzoylacetate, phenyl hydrazine, ethanol, 2-hydroxyaniline (o-aminophenol), o-aminobenzoic acid, p-aminobenzoic acid and diethyl ether; purchased from $\mathrm{BDH}$. Water used was bidistilled water; distillation process was carried out using both of condensation process and ion exchange technique. $10^{-3} \mathrm{M}$ of azopyrazolone solutions were prepared by dissolving a known mass of the azo compound in a proper volume of ethanol. $10^{-3} \mathrm{M}$ solution of the metal ion in $0.1 \mathrm{M} \mathrm{HCl}$ was prepared by dissolving the appropriate weight of the corresponding metal chlorides of $\mathrm{Cr}^{3+}, \mathrm{Mn}^{2+}, \mathrm{Co}^{2+}, \mathrm{Ni}^{2+}, \mathrm{Cu}^{2+}, \mathrm{Zn}^{2+}$ and $\mathrm{VOSO}_{4} \cdot 3 \mathrm{H}_{2} \mathrm{O}$ in a proper volume of $0.1 \mathrm{M} \mathrm{HCl}$ to prevent the hydrolysis of the metal salt solutions. Pure aqueous solutions of metal ions were also prepared for conductimetric studies. $0.1 \mathrm{M} \mathrm{HCl}$ was prepared and standardized against standard sodium carbonate solution, the exact concentration of the $\mathrm{HCl}$ solution was determined and used in calculations $(0.1185 \mathrm{M})$. $0.2 \mathrm{M}\left(\mathrm{CO}_{2}\right.$-free $) \mathrm{NaOH}$ solution was prepared and standardized against standard $\mathrm{HCl}$ solution. $\mathrm{NaCl}$ solutions with different concentrations (1, 0.6, 0.3 and $0.15 \mathrm{M}$ ) were also prepared. A series of buffer solutions covering the range (1.5-12) of $\mathrm{pH}$ values were prepared according to Britton method [14] with the modification involving titration of $100 \mathrm{ml}$ of the mixture (0.1 M solution of equal amounts of boric, acetic and phosphoric acids) with $0.5 \mathrm{M} \mathrm{NaOH}$ to the desired $\mathrm{pH}$ and then making with water up to $250 \mathrm{ml}$ so as to keep the ionic strength constant at all $\mathrm{pH}$ values [15].

\subsection{Preparation of 3-Methyl-1-Phenyl-5- Pyrazolone and 1, 3-Diphenyl-5- Pyrazolone}

A mixture of ethylacetoacetate $(6.5 \mathrm{~g} ; 0.05 \mathrm{M})$ and phenyl hydrazine $(5.4 \mathrm{~g} ; 0.05 \mathrm{M})$ or ethylbenzoylacetate $(9.6 \mathrm{~g} ; 0.05 \mathrm{M})$ and phenyl hydrazine $(5.4 \mathrm{~g} ; 0.05 \mathrm{M})$ was heated in water bath at $100^{\circ} \mathrm{C}$ for one hour [7]. The resulting oil was cooled and stirred with diethyl ether $(50 \mathrm{ml})$ until solidification occurred, the crude product was then filtered off, washed with ether until all colored material removed. The final product was recrystallized with $20 \%$ ethanol-water solution and collected as white powder of 3-methyl-1-phenyl-5-pyrazolone, yield 90\%, m.p. $131{ }^{\circ} \mathrm{C}$ or 1,3 -diphenyl-5-pyrazolone, yield $90 \%$, m.p. $143^{\circ} \mathrm{C}$.

\subsection{Preparation of Azopyrazolone Derivatives}

A well-stirred solution of 2-aminophenol, 2-aminobenzoic acid or 4-aminobenzoic acid $0.01 \mathrm{M}$ in $40 \mathrm{ml}$ ethanol and $20 \mathrm{ml}$ of $2 \mathrm{M} \mathrm{HCl}$ was cooled in an ice-salt bath and diazotized with aqueous sodium nitrite solution $(20 \mathrm{ml}, 0.01 \mathrm{M})$. The cooled $\left(0-5^{\circ} \mathrm{C}\right)$ diazonium solution was added slowly to a well-stirred solution of $0.01 \mathrm{M}$ 3-methyl-1-phenyl-5-pyrazolone or 1, 3-diphenyl-5-pyrazolone in $100 \mathrm{ml}$ ethanol containing sodium hydroxide $(10 \mathrm{~g})$. The reaction mixture was stirred for one hour at room temperature, and then acidified with dilute $\mathrm{HCl}$ $(100 \mathrm{ml}, 2.5 \mathrm{M})$ to neutralize the reaction mixture and precipitate the azopyrazolone derivatives [16]. The products were recrystallized from ethanol to give the derivatives of both 3-methyl-1-phenyl-4-arylazo-5-pyrazolone and 1, 3-diphenyl-4-arylazo-5-pyrazolone. The resulting derivatives have the following formulae:

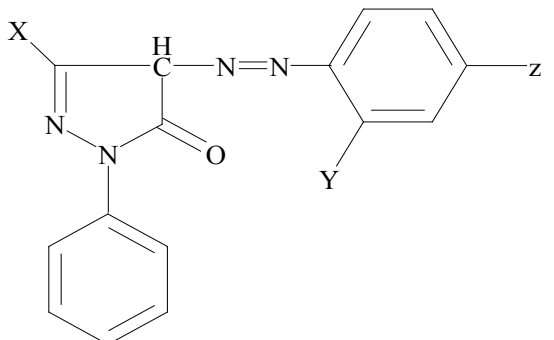

$\mathrm{X}=\mathrm{C}_{6} \mathrm{H}_{5}, \mathrm{Y}=\mathrm{COOH}, \mathrm{Z}=\mathrm{H}$;

1, 3-diphenyl-4-(o-carboxyphenylazo)-5-pyrazolone (L1),

$\mathrm{X}=\mathrm{CH}_{3}, \mathrm{Y}=\mathrm{COOH}, \mathrm{Z}=\mathrm{H}$;

3-methyl-1-phenyl-4-(o-carboxyphenylazo)-5-pyrazolone

(L2), $\mathrm{X}=\mathrm{C}_{6} \mathrm{H}_{5}, \mathrm{Y}=\mathrm{OH}, \mathrm{Z}=\mathrm{H}$;

1, 3-diphenyl-4-(o-hydroxyphenylazo)-5-pyrazolone (L3),

$\mathrm{X}=\mathrm{CH}_{3}, \mathrm{Y}=\mathrm{OH}, \mathrm{Z}=\mathrm{H}$;

3-methyl-1-phenyl-4-(o-hydroxyphenylazo)-5-pyrazolone (L4), $\mathrm{X}=\mathrm{C}_{6} \mathrm{H}_{5}, \mathrm{Y}=\mathrm{H}, \mathrm{Z}=\mathrm{COOH}$;

1, 3-diphenyl-4-(p-carboxyphenylazo)-5-pyrazolone (L5), $\mathrm{X}=\mathrm{CH}_{3}, \mathrm{Y}=\mathrm{H}, \mathrm{Z}=\mathrm{COOH}$;

3-methyl-1-phenyl-4-(p-carboxyphenylazo)-5-pyrazolone (L6).

Elemental analysis, IR, mass and ${ }^{1} \mathrm{H}$ NMR spectra were carried out to confirm their structures.

\section{4. pH-Metric Titration}

The experimental procedure involved the titration of the following solutions (total volume $=50 \mathrm{ml}$ ) against a standard $\mathrm{CO}_{2}$-free $(0.21 \mathrm{M}) \mathrm{NaOH}$ solution:

1) $5 \mathrm{ml}$ of $\mathrm{HCl}(0.12 \mathrm{M})+5 \mathrm{ml}$ of $\mathrm{NaCl}(1 \mathrm{M})+20 \mathrm{M}$ ethanol,

2) Solution $\mathrm{a}+20 \mathrm{ml}$ of $10^{-3} \mathrm{M}$ of the ligand under investigation, and, 
3) Solution $\mathrm{b}+5 \mathrm{ml}$ of metal salt solution $\left(10^{-3} \mathrm{M}\right)$.

These titrations were repeated for 1 ) ionic strengths $I$ $=0.167,0.1,0.05$, and $0.25 \mathrm{M} \mathrm{NaCl}$, at $\left.25^{\circ} \mathrm{C}, 2\right)$ various temperatures $\left(25,30,35\right.$, and $\left.45^{\circ} \mathrm{C}\right)$ at $I=0.167 \mathrm{M} \mathrm{NaCl}$.

The $\mathrm{pH}$ measurements were carried out using a Jenway, $\mathrm{pH}$-meter 3310 with a glass combined electrode. The water thermostat was a Thermo Haake WKL 26, Karlsruhe, Germany accurate to $\pm 0.1^{\circ} \mathrm{C}$. The solutions were equilibrated in the thermostat for about $15 \mathrm{~min}$ before titration. The equations used for the various calculations [17] were programmed into IBM computer.

\subsection{Determination of the Thermodynamic Parameters}

The following thermodynamic parameters: $\Delta G^{\circ}, \Delta H^{\circ}$ and $\Delta S^{\circ}$ were determined for each chelate depending on their stability constants [18]. The free energy of formation $\left(\Delta G^{\circ}\right)$ of a complex is related to its stability constant by the relation [18]: $-\Delta G^{\circ}=2.303 R T \log \beta$ where, $R=$ universal gas constant, $T=$ absolute temperature and $\log \beta=$ stability constant of the complex. Enthalpy of formation $\left(\Delta H^{\circ}\right)$ and entropy $\left(\Delta S^{\circ}\right)$ were calculated by plotting $\log \beta$ versus $1 / T$. We can specify the quantitative dependence of the stability constant on temperature from the relation [18]:

$$
\begin{gathered}
\Delta G^{\circ}=\Delta H^{\circ}-T \Delta S^{\circ} \\
\Delta G^{\circ}=-2.303 R T \log \beta=\Delta H^{\circ}-T \Delta S^{\circ}
\end{gathered}
$$

By rearranging, we get

$$
\log \beta=-\Delta H^{\circ} /(2.303 R T)+\Delta S^{\circ} /(2.303 R)
$$

This is a linear equation of the form $\mathrm{y}=\mathrm{mx}+\mathrm{b}$, where $\mathrm{y}=\log \beta, \mathrm{m}=-\Delta H^{\circ} /(2.303 R)=$ slope, $\mathrm{x}=1 / T$, and $\mathrm{b}=\Delta S^{\circ} /(2.303 \mathrm{R})=$ intercept. This means that if the values of $K$ for a given reaction are determined at various temperature, a plot of $\log \beta$ versus $1 / T$ will be linear, with slope $\Delta H^{\circ} /(2.303 R)$ and intercept $\Delta S^{\circ} /(2.303 R)$. This result assumes that both $\Delta H^{\circ}$ and $\Delta S^{\circ}$ are independent of temperature over the temperature range considered. This assumption is a good approximation over a relatively small temperature range [18].

\subsection{Conductimetric Measurements}

The conductivities of $\mathrm{VO}^{2+}, \mathrm{Cr}^{3+}, \mathrm{Mn}^{2+}, \mathrm{Co}^{2+}, \mathrm{Ni}^{2+}, \mathrm{Cu}^{2+}$ and $\mathrm{Ni}^{2+}$ metal ions with the investigated ligands (L1-L6) were measured using conductivity meter (Philips pw 9526, digital conductivity meter). The experimental procedure involves a conductimetric titration of $40 \mathrm{ml}$ alcohol-water mixture $(50 \% \mathrm{v} / \mathrm{v})$ solution containing $4 \times$ $10^{-5} \mathrm{M}$ of a given azopyrazolone derivative against a standard solution of $10^{-3} \mathrm{M}$ aqueous metal ion solution using microburette with continuous magnetic stirring. The instrument reading was recorded after each addition. All of the conductivity values were corrected for the effect of dilution during titration. Corrections were made by multiplying conductivity value (instrument reading) by the ratio $(\mathrm{V}+\mathrm{v}) / \mathrm{V}$, where $\mathrm{V}$ is the original volume of the titrand $(40 \mathrm{ml}$ and $\mathrm{v}$ is the added volume of titrant [19]). The corrected conductivity values were plotted versus the molar ratio (L:M). The resulting curves are composed of straight lines with inflection points indicating the number of ligands around each central metal ion.

\subsection{Spectrophotometric Method Applied for Determination of $\mathrm{PK}_{\mathrm{a}}$ Values}

The absorption spectra of azopyrazolone compounds under investigation (L1-L6) were scanned over a range of wavelengths in universal buffer solutions of different $\mathrm{pH}$ values. For this purpose a known volume of $\left(10^{-3} \mathrm{M}\right)$ solution of the azopyrazolone derivative was added to the buffer solution in a $10 \mathrm{ml}$ volumetric flask dropwise with continuous shaking. The mixture was then made up to the mark with the buffer solution of appropriate $\mathrm{pH}$. The spectra were obtained at room temperature using spectrophotometer (Jenway, 6305 UV-VIS spectrophotometer).

The method applied for the determination of $\mathrm{pK}_{\mathrm{a}}$ values of the different azopyrazolone derivatives is the half height method [20]. This method depends on the fact that the limiting absorbance $\left(A_{1}\right)$ represents complete conversion of the compound from one form to other. Since $\mathrm{pKa}$ is equal to the $\mathrm{pH}$ value at which the two forms exist in equivalent amounts $\left(\mathrm{pK}_{\mathrm{a}}=\mathrm{pH}\left(\right.\right.$ at $\left.A_{1 / 2}\right)$, the $\mathrm{pH}$ corresponding to half the height of the absorbance-pH curve $\left(A_{1 / 2}\right)$ is equal to $\mathrm{pK}_{\mathrm{a}}$. The $\left(A_{1 / 2}\right)$ value is given by the relation:

$$
A_{1 / 2}=\frac{A_{1}-A_{\min }}{2}+A_{\text {min }}
$$

where $A_{1}=$ maximum absorbance, $A_{\min }=$ minimum absorption.

The absorption spectra of $3 \times 10^{-5} \mathrm{M}$ solutions of the azopyrazolones under investigation (ligands L1-L6) were dissolved in $40 \% \mathrm{v} / \mathrm{v}$ ethanolic buffer solutions of varying $\mathrm{pH}$ values.

\subsection{Determination of the Molar Ratio of the Metal Lons to the Ligands Spectrophotometrically}

The mole ratio of the metal ions to the ligands was studied spectrophotometrically using molar ratio and continuous variation methods. The spectrophotometric method was used to confirm the data obtained by conductimetric and $\mathrm{pH}$-metric methods. UV absorption can be used to determine stoichiometry of the complexes and this method appears to be valuable for studying complexes with low stabilities. 


\subsubsection{Molar Ratio Method}

In this investigation, the concentration of the metal ions were maintained constant and the ligands concentrations were varied [21], so a series of metal-ligand aqueous ethanolic solutions were prepared with different $[\mathrm{L}] /[\mathrm{M}]$ ratios. The absorptions of these solutions were measured using UV spectrophotometer at $\lambda_{\max }$ of the expected complex $\mathrm{ML}_{2}$. Absorbance versus [L]/[M] curves were drawn for all complexes.

\subsubsection{Continuous Variation Method}

This method was used to confirm the data obtained using molar ratio and conductivity methods. In this method, the mole fraction was varied by changing the concentrations of the two components, maintaining the total number of moles constant [21]. A series of metal-ligand aqueous ethanolic solutions were prepared with different metal mole fractions. The mole fraction of the metal was plotted against the absorbance of the expected complex at $\lambda_{\max }$ of the complex. The measured absorbance increase as the molar ratio $[\mathrm{M}] /([\mathrm{L}]+[\mathrm{M}])$ increase until the actual molar ratio of the complex is reached, after this point the absorbance becomes lower because the metal has no absorption at $\lambda_{\max }$ of the complex.

\section{RESULTS AND DISCUSSION}

\subsection{Determination of Stability Constants}

Titration curves were obtained for the titrations of $\mathrm{VO}^{2+}$, $\mathrm{Cr}^{3+}, \mathrm{Mn}^{2+}, \mathrm{Co}^{2+}, \mathrm{Ni}^{2+}, \mathrm{Cu}^{2+}$ and $\mathrm{Zn}^{2+}$ metal ions in the presence of different molarities of $\mathrm{NaCl}$ and different temperatures. The stability constants of the formed complexes were investigated in the $\mathrm{pH}$ range of 4-6.

The mean values of $n_{H}$ (the average number of protons associated with the ligand) for the investigated ligands (L1-L6) at different $\mathrm{pH}$ values were calculated from the titration curves of solutions 1 and 2 by employing the relationship derived by Irving and Rossotti [17]. On plotting $\log n_{H} /\left(1-n_{H}\right)$ vs. $\mathrm{pH}$, a straight lines having an intercept equal to $\mathrm{pK}_{\mathrm{a}}$ on the $\mathrm{pH}$ axis are obtained. From the titration curves of solutions 1-3, the metal + ligand formation number values $\bar{n}$ (the average number of ligand molecules coordinated to the metal ion) of the metal complexes were obtained at various $\mathrm{pH}$ values. The $\bar{n}$ values were found to be less or equal to 2 , indicating the formation of $1: 1$ and 1:2 complexes. The $\bar{n}$ values were calculated using the Irving and Rossotti formulation [17]. The free ligand exponent $p L$ was calculated from the so obtained values of $\bar{n}$ by the equation:

$$
p L=\log \left[\frac{\sum_{y=0}^{y=1} \beta_{y}^{H}\left(\frac{1}{10^{B}}\right)}{C_{L}-\bar{n} C_{M}} \frac{V_{o}+V_{c}}{V_{o}}\right]
$$

where, $C_{M}$ is the concentration of ions $\mathrm{M}^{\mathrm{n}+}$ used, $C_{L}$ is the concentration of the ligand, $y$ is the number of dissociable protons ( $y=1$ for the investigated ligands), and $V_{o}$ is the original volume $(50 \mathrm{ml}), V_{c}$ is the volume of alkali $(\mathrm{NaOH})$ consumed to reach the same $\mathrm{pH}$ values in curve $c$ corresponding to the titration of solution $3, \beta_{y}^{H}$ is the formation constant values of the investigated ligands, and $B$ is the $\mathrm{pH}$ value. The mean $\mathrm{pK}_{\mathrm{a}}$ values obtained from the corresponding different experimental formation curves using the average value and straight line methods. The results obtained for proton-ligand systems $\left(\mathrm{pK}_{\mathrm{a}}\right.$ values) were $3.98,4.04,7.68,7.93,3.45$ and 3.66 for the investigated ligands L1-L6, respectively. Referring to these data, the $\mathrm{pK}_{\mathrm{a}}$ values of ligands L5 and L6 have the lowest values from all of the six ligands used in this work because the ionizble group $(-\mathrm{COOH})$ locates in the para position where there is no attraction with the carbonyl group of the pyrazolone ring, so it is easy to lose $\mathrm{H}^{+}$ion, whereas the ligands $\mathrm{L} 1$ and $\mathrm{L} 2$ have $\mathrm{pK}_{\mathrm{a}}$ values higher than L5 and L6 because the ionizable group $(-\mathrm{COOH})$ locates in ortho position, so there is a hydrogen bond between the carbonyl group of the pyrazolone ring and $-\mathrm{COOH}$, as a result; it is more difficult to lose $\mathrm{H}^{+}$, so these two ligands have $\mathrm{pK}_{\mathrm{a}}$ values higher than L5 and L6 [22]. The $\mathrm{pK}_{\mathrm{a}}$ values of ligands L3 and L4 have the highest values from all because the ionizable group of these two ligands $(-\mathrm{OH})$ locates in ortho position with lower ability to librate $\mathrm{H}^{+}$ion because hydroxyl group has lower acidity than carboxyl group and because of the presence of hydrogen with the carbonyl group of the pyrazolone ring [23]. Ligand L1 has $\mathrm{pK}_{\mathrm{a}}$ value $<\mathrm{L} 2$, and L3 $<$ L4, and L5 $<$ L6, that is because of the presence of additional phenyl group (electron withdrawing group) in ligands L1, L3 and L5. The formation curves for the complexes were obtained by plotting the relation between average number of ligands attached per metal ion $(\bar{n})$ and free ligand exponent $(p L), \bar{n}$ and $p L$ were calculated as previously mentioned. To compute successive stability constants $\left(\log \beta_{1}\right.$ and $\left.\log \beta_{2}\right)$ the method of interpolation is used [17], where $\log \beta_{1}$ and $\log \beta_{2}$ are equal to the values of $(p L)$ when $(\bar{n})=0.5$ and 1.5 , respectively. $\log \beta_{1}$ and $\log \beta_{2}$ for all complexes are given in Table 1.

\subsection{Relations between the Properties of Central Metal Lons and the Stability Constants of the Complexes}

The transition metal ions form predominantly ionic and coordinate bonds. If the bonds are ionic, the born rela- 
Table 1. Collective data of stability constants $\left(\log \beta_{1}\right.$ and $\left.\log \beta_{2}\right)$ for all of the investigated complexes.

\begin{tabular}{|c|c|c|c|c|c|c|c|c|c|c|c|c|c|c|}
\hline \multirow[t]{2}{*}{ Ligand } & \multicolumn{2}{|c|}{$\mathrm{VO}^{2+}$} & \multicolumn{2}{|c|}{$\mathrm{Cr}^{3+}$} & \multicolumn{2}{|c|}{$\mathrm{Mn}^{2+}$} & \multicolumn{2}{|c|}{$\mathrm{Co}^{2+}$} & \multicolumn{2}{|c|}{$\mathrm{Ni}^{2+}$} & \multicolumn{2}{|c|}{$\mathrm{Cu}^{2+}$} & \multicolumn{2}{|c|}{$\mathrm{Zn}^{2+}$} \\
\hline & $\log \beta_{1}$ & $\log \beta_{2}$ & $\log \beta_{1}$ & $\log \beta_{2}$ & $\log \beta_{1}$ & $\log \beta_{2}$ & $\log \beta_{1}$ & $\log \beta_{2}$ & $\log \beta_{1}$ & $\log \beta_{2}$ & $\log \beta_{1}$ & $\log \beta_{2}$ & $\log \beta_{1}$ & $\log \beta_{2}$ \\
\hline L1 & 3.78 & 5.83 & 3.92 & 6.04 & 3.53 & 5.29 & 3.99 & 6.18 & 4.08 & 6.38 & 4.21 & 6.60 & 4.02 & 6.23 \\
\hline L2 & 4.72 & 7.70 & 4.78 & 7.31 & 4.71 & 7.52 & 4.90 & 8.04 & 4.83 & 7.53 & 4.87 & 7.41 & 4.82 & 7.25 \\
\hline L3 & 5.63 & 9.54 & 5.65 & 9.93 & 5.43 & 8.81 & 5.67 & 10.06 & 5.75 & 10.07 & 5.76 & 9.94 & 5.73 & 9.87 \\
\hline L4 & 5.77 & 9.76 & 5.79 & 10.15 & 5.63 & 9.50 & 5.80 & 9.91 & 5.90 & 10.14 & 5.94 & 10.47 & 5.84 & 10.19 \\
\hline L5 & 3.26 & 4.29 & 3.60 & 5.68 & 3.25 & 5.34 & 3.75 & 5.85 & 3.83 & 6.71 & 3.83 & 5.68 & 3.78 & 6.66 \\
\hline L6 & 4.26 & 6.34 & 4.33 & 6.78 & 4.25 & 6.78 & 4.37 & 8.05 & 4.52 & 8.55 & 4.58 & 8.01 & 4.46 & 8.37 \\
\hline
\end{tabular}

tion $\left(E=Z^{2} / 2 r[1-1 / D]\right)[24]$ can be hold for the energy change on complexation of an ion of charge $(Z)$ and radius (r) [25-27] in a medium of dielectric constant (D). Since the stability constant is related directly to this energy, $\log \beta$ values should increase linearly with $Z^{2} /$ r. The stability constants of some transition metal complexes show different behaviors which suggest the probable existence of linearity and nonlinearity of $\log \beta$ with $Z^{2} / \mathrm{r}$ [28]. The plots of $\log \beta_{1}$ and $\log \beta_{2}$ versus $Z^{2} / \mathrm{r}$ of the transition metal ions $\left(\mathrm{VO}^{2+}, \mathrm{Cr}^{3+}, \mathrm{Mn}^{2+}, \mathrm{Co}^{2+}, \mathrm{Ni}^{2+}\right.$, $\mathrm{Cu}^{2+}$ and $\mathrm{Zn}^{2+}$ ) complexes with the investigated ligands (L1-L6), does not exhibit linear increase of $\log \beta$ with increase of $Z^{2} /$ r. Interpretation in term of the assumption about ionic character of metal-ligand on which the linearity based is not valid. The other probable case is steric effects. It is also interest to study the $\log \beta_{1}$ and $\log \beta_{2}$ values of the transition metal complexes with the investigated ligands (L1-L6) as a function of atomic number $1 / \mathrm{r}$ (the inverse of ionic radius) as well as EN (electronegativity) [28] of metal ions. In this investigation, it was found that the stability constants of the first raw transition metal complexes with the investigated ligands (L1-L6) ( $\log \beta$ values) are generally increase with decreasing ionic radius $r$ (or increasing $1 / \mathrm{r}$ ) and increase with increasing atomic number [29], also $\log \beta$ increases with increasing electonegativity, this is because upon increasing electronegativity of the metal ions, the electronegativity difference between the metal atom and the donor atom of the ligand would expectedly associate with increase of covalent character of the metal-ligand bond. These relations are not linear and there are some exceptions from the mentioned observations because of the presence of steric effects and ionic bonds. The relations between the ionization constants $\left(\mathrm{pK}_{\mathrm{a}}\right)$ of the ligands and the stability constants $\left(\log \beta_{1}, \log \beta_{2}\right)$ of their complexes with the transition metal ions $\left(\mathrm{VO}^{2+}, \mathrm{Cr}^{3+}\right.$, $\mathrm{Mn}^{2+}, \mathrm{Co}^{2+}, \mathrm{Ni}^{2+}, \mathrm{Cu}^{2+}$ and $\mathrm{Zn}^{2+}$ ) can be studied. It is observed that as $\mathrm{pK}_{\mathrm{a}}$ of the ligand increases, the stability constant $\log \beta$ of the complex increase. The semi linear correlation observed in this study demonstrates that factors which increase or decrease $\mathrm{pK}_{\mathrm{a}}$ of the ligand also affect the $\log K_{M L}$ values for the metal ions in a parallel fashion. This means that substituent groups that tend to increase electron density on donor atom and hence tend to increase the coordination ability of the ligand increase $\log K_{M L}$, and also increase the value of $\mathrm{pK}_{\mathrm{a}}$ of the ionizable hydrogen [29]. The assumption here is that ligand basicity is directly related to ligand stability i.e., more stable complexes being formed from basic ligands [29]. Such correlation cannot be generalized because of the presence of some exceptions from linearity and because this result was observed form the ligands and the metal ions used in this study only.

\subsection{Effect of Lonic Strength on Stability Constants}

The stability constants of the metal ions $\left(\mathrm{VO}^{2+}, \mathrm{Cr}^{3+}\right.$, $\mathrm{Mn}^{2+}, \mathrm{Co}^{2+}, \mathrm{Ni}^{2+}, \mathrm{Cu}^{2+}$ and $\mathrm{Zn}^{2+}$ ) complexes with the investigated ligands (L1-L6) were found to decrease with increasing ionic strength of the medium as shown in Table 2. For each complex the relationship between the stability constant and the square root of the ionic strength is plotted in Figures 1, 2 and was in agreement with the Debye-Hückel equation [30]. The thermodynamic stability constants $\left(\log \beta^{\circ}\right)$ were obtained by extrapolating the straight line plots of $\log \beta$ versus $\sqrt{\mathrm{I}}$ to zero ionic strength. From the plots of $\log \beta$ versus $\sqrt{\mathrm{I}}$ which illustrated in Figures 1 and 2, the $\log \beta^{\circ}$ (thermodynamic stability constants) values were obtained and listed in Table 3. Also values of $\mathrm{pK}_{\mathrm{a}}$ were found to decrease with increasing ionic strength of the medium which are in agreement with Debye-Hückel equation [30,31]. The equation $\Delta \mathrm{G}=-2.303 R T \log \beta$ gives the relationship between the thermodynamic stability con- 
Table 2. Stability constants of $\mathrm{VO}^{2+}, \mathrm{Cr}^{3+}, \mathrm{Mn}^{2+}, \mathrm{Co}^{2+}, \mathrm{Ni}^{2+}, \mathrm{Cu}^{2+}$ and $\mathrm{Zn}^{2+}$ complexes with the investigated ligands L1-L6 at different ionic strengths at room temperature.

\begin{tabular}{|c|c|c|c|c|}
\hline \multirow[t]{2}{*}{ Complex } & \multicolumn{4}{|c|}{$\mathrm{I}(\mathrm{mol} / \mathrm{l} \mathrm{NaCl})$} \\
\hline & 0.167 & 0.1 & 0.05 & 0.025 \\
\hline \multicolumn{5}{|l|}{ L1- } \\
\hline $\mathrm{VO}^{2+}$ & 5.83 & 6.16 & 6.64 & 6.99 \\
\hline $\mathrm{Cr}^{3+}$ & 6.04 & 6.38 & 6.90 & 7.18 \\
\hline $\mathrm{Mn}^{2+}$ & 5.29 & 5.78 & 6.12 & 6.54 \\
\hline $\mathrm{Co}^{2+}$ & 6.18 & 6.5 & 7.00 & 7.29 \\
\hline $\mathrm{Ni}^{2+}$ & 6.23 & 6.72 & 7.30 & 7.67 \\
\hline $\mathrm{Cu}^{2+}$ & 6.60 & 7.27 & 7.59 & 8.03 \\
\hline $\mathrm{Zn}^{2+}$ & 6.23 & 6.60 & 7.15 & 7.41 \\
\hline \multicolumn{5}{|l|}{ L2- } \\
\hline $\mathrm{VO}^{2+}$ & 7.70 & 8.10 & 8.63 & 8.87 \\
\hline $\mathrm{Cr}^{3+}$ & 7.31 & 7.65 & 7.98 & 8.29 \\
\hline $\mathrm{Mn}^{2+}$ & 7.52 & 7.95 & 8.35 & 8.69 \\
\hline $\mathrm{Co}^{2+}$ & 8.04 & 8.40 & 8.90 & 9.23 \\
\hline $\mathrm{Ni}^{2+}$ & 7.53 & 7.85 & 8.20 & 8.63 \\
\hline $\mathrm{Cu}^{2+}$ & 7.41 & 7.70 & 8.10 & 8.50 \\
\hline $\mathrm{Zn}^{2+}$ & 7.25 & 7.50 & 7.90 & 8.07 \\
\hline \multicolumn{5}{|l|}{ L3- } \\
\hline $\mathrm{VO}^{2+}$ & 9.54 & 9.96 & 10.45 & 10.85 \\
\hline $\mathrm{Cr}^{3+}$ & 9.87 & 10.23 & 10.60 & 10.92 \\
\hline $\mathrm{Mn}^{2+}$ & 8.81 & 9.26 & 9.85 & 10.29 \\
\hline $\mathrm{Co}^{2+}$ & 10.06 & 10.50 & 10.86 & 11.21 \\
\hline $\mathrm{Ni}^{2+}$ & 10.07 & 10.60 & 11.10 & 11.52 \\
\hline $\mathrm{Cu}^{2+}$ & 9.94 & 10.25 & 10.70 & 11.03 \\
\hline $\mathrm{Zn}^{2+}$ & 9.93 & 10.35 & 10.90 & 11.45 \\
\hline \multicolumn{5}{|l|}{ L4- } \\
\hline $\mathrm{VO}^{2+}$ & 9.76 & 10.15 & 10.60 & 1.00 \\
\hline $\mathrm{Cr}^{3+}$ & 10.15 & 10.50 & 11.00 & 11.33 \\
\hline $\mathrm{Mn}^{2+}$ & 9.50 & 10.00 & 10.48 & 10.82 \\
\hline $\mathrm{Co}^{2+}$ & 9.91 & 10.36 & 10.75 & 11.12 \\
\hline $\mathrm{Ni}^{2+}$ & 10.14 & 10.45 & 10.89 & 11.20 \\
\hline $\mathrm{Cu}^{2+}$ & 10.47 & 10.85 & 11.31 & 11.66 \\
\hline $\mathrm{Zn}^{2+}$ & 10.19 & 10.68 & 11.14 & 11.51 \\
\hline \multicolumn{5}{|l|}{ L5- } \\
\hline $\mathrm{VO}^{2+}$ & 4.29 & 4.70 & 5.20 & 5.71 \\
\hline $\mathrm{Cr}^{3+}$ & 5.68 & 6.05 & 6.60 & 6.81 \\
\hline $\mathrm{Mn}^{2+}$ & 5.34 & 5.6 & 5.90 & 6.32 \\
\hline $\mathrm{Co}^{2+}$ & 5.85 & 6.20 & 6.70 & 7.12 \\
\hline $\mathrm{Ni}^{2+}$ & 6.71 & 7.00 & 7.40 & 7.89 \\
\hline $\mathrm{Cu}^{2+}$ & 6.70 & 7.25 & 7.60 & 8.12 \\
\hline $\mathrm{Zn}^{2+}$ & 6.66 & 6.80 & 7.20 & 7.60 \\
\hline \multicolumn{5}{|l|}{ L6- } \\
\hline $\mathrm{VO}^{2+}$ & 6.34 & 6.67 & 7.02 & 7.45 \\
\hline $\mathrm{Cr}^{3+}$ & 6.87 & 7.20 & 7.51 & 7.99 \\
\hline $\mathrm{Mn}^{2+}$ & 6.27 & 6.50 & 6.90 & 7.26 \\
\hline $\mathrm{Co}^{2+}$ & 8.05 & 8.51 & 9.03 & 9.50 \\
\hline $\mathrm{Ni}^{2+}$ & 8.55 & 9.14 & 9.63 & 9.84 \\
\hline $\mathrm{Cu}^{2+}$ & 8.01 & 8.23 & 8.80 & 9.05 \\
\hline $\mathrm{Zn}^{2+}$ & 8.37 & 8.80 & 9.35 & 9.72 \\
\hline
\end{tabular}


Table 3. The Thermodynamic stability constants $\left(\log \beta^{\circ}\right)$ of $\mathrm{VO}^{2+}, \mathrm{Cr}^{3+}, \mathrm{Mn}^{2+}, \mathrm{Co}^{2+}, \mathrm{Ni}^{2+}, \mathrm{Cu}^{2+}$ and $\mathrm{Zn}^{2+}$ complexes with the investigated ligands (L1-L6).

\begin{tabular}{cccccccc}
\hline Metal ion & $\mathrm{VO}^{2+}$ & $\mathrm{Cr}^{3+}$ & $\mathrm{Mn}^{2+}$ & $\mathrm{Co}^{2+}$ & $\mathrm{Ni}^{2+}$ & $\mathrm{Cu}^{2+}$ & $\mathrm{Zn}^{2+}$ \\
\hline L1 & 7.73 & 7.92 & 7.30 & 8.00 & 8.58 & 8.89 & 8.18 \\
L2 & 9.63 & 8.90 & 7.42 & 9.99 & 9.30 & 9.18 & 8.61 \\
L3 & 11.67 & 11.56 & 11.23 & 11.90 & 12.41 & 11.73 & 12.38 \\
L4 & 11.77 & 12.1 & 11.65 & 11.87 & 11.87 & 12.41 & 12.33 \\
L5 & 6.59 & 7.55 & 6.92 & 7.92 & 8.62 & 8.97 & 8.19 \\
L6 & 8.13 & 8.72 & 7.88 & 10.4 & 10.66 & 9.74 & 10.58 \\
\hline
\end{tabular}

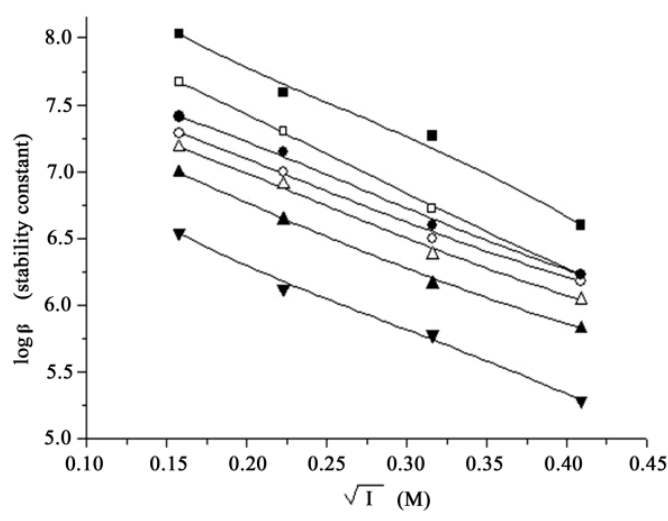

Figure 1. Plots of $\log \beta$ versus $\sqrt{\mathrm{I}}$ for L1 with the investigated metal ion complexes.

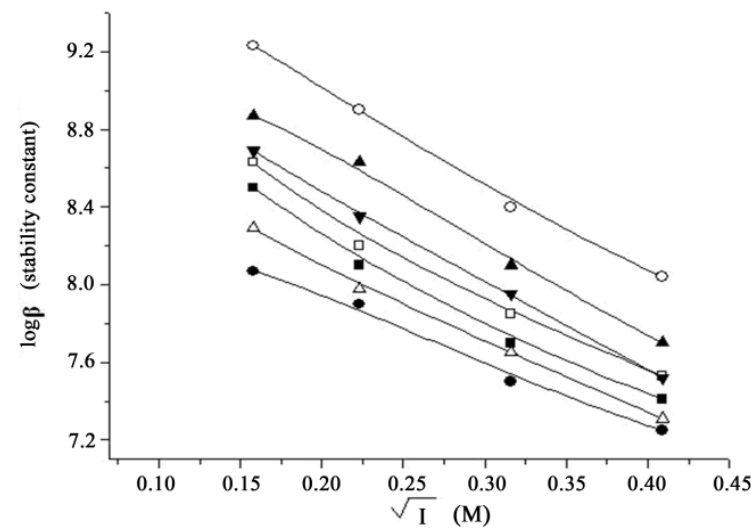

Figure 2. Plots of $\log \beta$ versus $\sqrt{\mathrm{I}}$ for L2 with the investigated metal ion complexes.

stant and the free energy change according to the complex formation.

\subsection{Effect of Temperature on Stability Constants}

From the $\mathrm{pK}_{\mathrm{a}}$ and $\log \beta$ values and their temperature dependence, the values of the thermodynamic functions $\Delta \mathrm{G}, \Delta \mathrm{H}$ and $\Delta \mathrm{S}$ were calculated [32]. The values of stability constants in Table 4 reveal that the stability con- stants decrease with increasing temperature, along with the $\mathrm{pK}_{\mathrm{a}}$ value (Figures 3, 4).

\subsection{Conductimetric Measurements}

The calculated molar ratio $[\mathrm{L}] /[\mathrm{M}]$ were plotted against the corrected molar conductance values. The results indicated that the conductance increases with the addition of the metal ion solutions due to the release of the highly conducting hydrogen ions as a result of chelation. In-

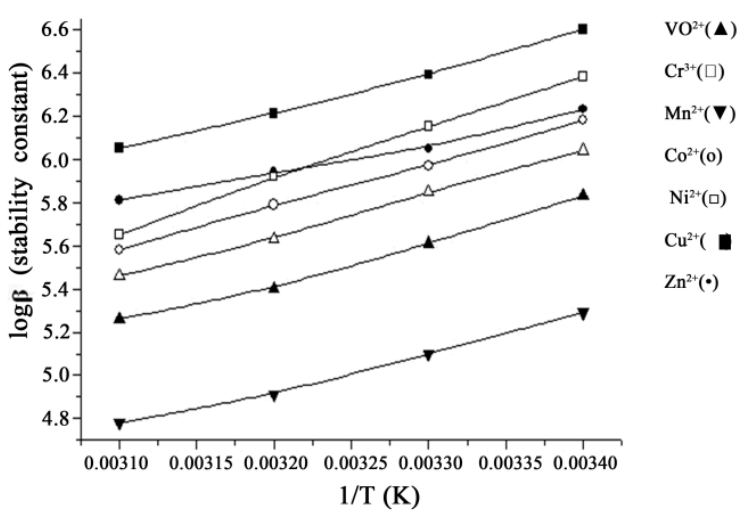

Figure 3. Plots of $\log \beta$ versus $1 / \mathrm{T}$ for $\mathrm{L} 1$ with the investigated metal ion complexes.

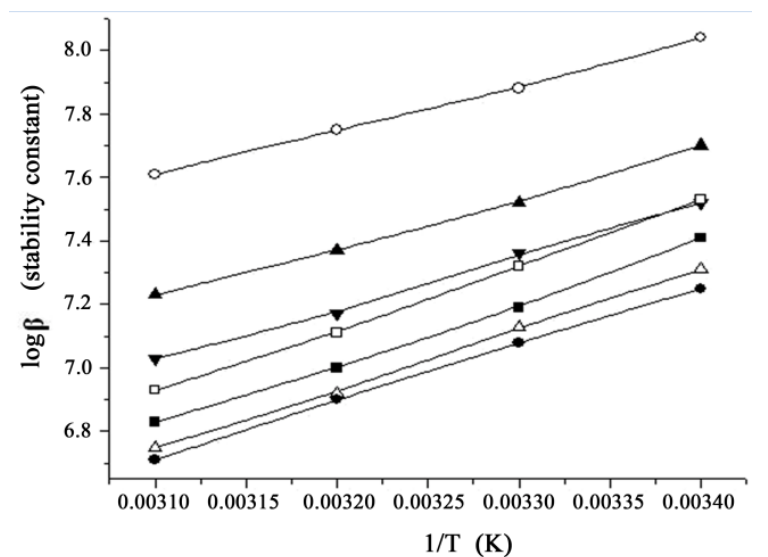

Figure 4. Plots of $\log \beta$ versus $1 / \mathrm{T}$ for $\mathrm{L} 2$ with investigated metal ion complexes. 
Table 4. The thermodynamic parameters $\left(\Delta \mathrm{H}^{\circ}, \Delta \mathrm{G}^{\circ}\right.$ and $\left.\Delta \mathrm{S}^{\circ}\right)$ for $\mathrm{VO}^{2+}, \mathrm{Cr}^{3+}, \mathrm{Mn}^{2+}, \mathrm{Co}^{2+}, \mathrm{Ni}^{2+}, \mathrm{Cu}^{2+}$ and $\mathrm{Zn}^{2+}$ complexes with the investigated ligands (L1-L6).

\begin{tabular}{|c|c|c|c|c|c|c|c|c|}
\hline & & $\mathrm{VO}^{2+}$ & $\mathrm{Cr}^{3+}$ & $\mathrm{Mn}^{2+}$ & $\mathrm{Co}^{2+}$ & $\mathrm{Ni}^{2+}$ & $\mathrm{Cu}^{2+}$ & $\mathrm{Zn}^{2+}$ \\
\hline & $-\Delta \mathrm{G}^{\circ}(\mathrm{kJ} / \mathrm{mol})$ & 32.984 & 34.318 & 29.899 & 34.974 & 36.047 & 37.29 & 35.224 \\
\hline \multirow[t]{3}{*}{ L1 } & $-\Delta \mathrm{H}^{\circ}(\mathrm{kJ} / \mathrm{mol})$ & 36.77 & 37.53 & 32.94 & 37.92 & 46.34 & 35.04 & 26.23 \\
\hline & $+\Delta \mathrm{S}^{\circ}(\mathrm{kJ} / \mathrm{mol} . \mathrm{K})$ & -0.013 & -0.013 & -0.011 & -0.011 & -0.035 & 0.007 & 0.03 \\
\hline & $-\Delta \mathrm{G}^{\circ}(\mathrm{kJ} / \mathrm{mol})$ & 43.122 & 40.966 & 42.157 & 44.995 & 42.184 & 41.47 & 40.63 \\
\hline \multirow[t]{3}{*}{ L2 } & $-\Delta \mathrm{H}^{\circ}(\mathrm{kJ} / \mathrm{mol})$ & 29.87 & 36.19 & 31.79 & 27.19 & 38.49 & 36.96 & 34.47 \\
\hline & $+\Delta \mathrm{S}^{\circ}(\mathrm{kJ} / \mathrm{mol} . \mathrm{K})$ & 0.046 & 0.017 & 0.036 & 0.062 & 0.013 & 0.016 & 0.022 \\
\hline & $-\Delta \mathrm{G}^{\circ}(\mathrm{kJ} / \mathrm{mol})$ & 54.194 & 56.314 & 49.963 & 57.071 & 57.147 & 56.371 & 55.955 \\
\hline \multirow[t]{3}{*}{ L3 } & $-\Delta \mathrm{H}^{\circ}(\mathrm{kJ} / \mathrm{mol})$ & 35.85 & 34.47 & 39.64 & 36.96 & 33.32 & 40.98 & 42.89 \\
\hline & $+\Delta \mathrm{S}^{\circ}(\mathrm{kJ} / \mathrm{mol} . \mathrm{K})$ & 0.064 & 0.073 & 0.034 & 0.067 & 0.08 & 0.051 & 0.043 \\
\hline & $-\Delta \mathrm{G}^{\circ}(\mathrm{kJ} / \mathrm{mol})$ & 55.724 & 58.001 & 54.258 & 56.561 & 57.932 & 59.878 & 58.179 \\
\hline \multirow[t]{3}{*}{ L4 } & $-\Delta \mathrm{H}^{\circ}(\mathrm{kJ} / \mathrm{mol})$ & 31.41 & 27.77 & 35.24 & 36.77 & 38.49 & 40.98 & 33.70 \\
\hline & $+\Delta \mathrm{S}^{\circ}(\mathrm{kJ} / \mathrm{mol} . \mathrm{K})$ & 0.08 & 0.1 & 0.062 & 0.065 & 0.063 & 0.061 & 0.081 \\
\hline & $-\triangle \mathrm{G}^{\circ}(\mathrm{kJ} / \mathrm{mol})$ & 24.518 & 32.473 & 30.499 & 33.4 & 38.284 & 38.292 & 38.012 \\
\hline \multirow[t]{3}{*}{ L5 } & $-\Delta \mathrm{H}^{\circ}(\mathrm{kJ} / \mathrm{mol})$ & 20.68 & 36.19 & 28.34 & 41.94 & 55.53 & 29.68 & 32.94 \\
\hline & $+\Delta \mathrm{S}^{\circ}(\mathrm{kJ} / \mathrm{mol} . \mathrm{K})$ & 0.012 & -0.014 & 0.006 & -0.031 & -0.06 & 0.027 & 0.016 \\
\hline & $-\Delta \mathrm{G}^{\circ}(\mathrm{kJ} / \mathrm{mol})$ & 35.87 & 38.307 & 35.438 & 45.514 & 48.357 & 45.288 & 47.307 \\
\hline \multirow[t]{2}{*}{ L6 } & $-\Delta \mathrm{H}^{\circ}(\mathrm{kJ} / \mathrm{mol})$ & 34.85 & 34.09 & 39.26 & 24.13 & 36.19 & 32.17 & 35.42 \\
\hline & $+\Delta \mathrm{S}^{\circ}(\mathrm{kJ} / \mathrm{mol} . \mathrm{K})$ & 0.003 & 0.014 & -0.013 & 0.072 & 0.041 & 0.044 & 0.04 \\
\hline
\end{tabular}

spection of the titration curves shows the presence of two distinctive breaks at metal to ligand molar rations of $1: 1$ and $1: 2$, respectively.

\subsection{Spectrophotometric Determination of the $\mathrm{pK}_{\mathrm{a}}$ Values of the Investigated Ligands}

The absorption spectra were recorded to investigate the spectral properties of the species liable to exist in such media and to determine the ionization constant $\left(\mathrm{pK}_{\mathrm{a}}\right)$ values of the acidic groups present. Britton-Robinson universal buffers [14] were used to control the $\mathrm{pH}$ over the range 1.5-12.0. The maximum absorption of the ligand increases as $\mathrm{pH}$ of the buffer increase. The spectra in acidic solutions of $\mathrm{pH}$ 1.5-6.0 are characterized by a strong band absorbing maximally within the wavelength range $370-400 \mathrm{~nm}$. These bands are due to absorption of the nonionized form liable to exist in such solutions and may be assigned to $\pi-\pi^{*}$ electronic transition within the ligand molecule influenced by intramolecular charge transfer. The spectra in alkaline solutions are characterized by the presence of a strong band absorbing maximally at the same range, which may be assigned to the absorption of the ionized form liable to exist at high $\mathrm{pH}$ values as a result of acid base equilibrium. It is noted in this investigation that the absorption bands assigned to the ionized form increases gradually by increasing of $\mathrm{pH}$, attaining the maximum value at $\mathrm{pH}$ 10-12.0. The absorbance-pH curves show that the absorbance attains a limiting value at the extreme $\mathrm{pH}$ values in highly acidic or alkaline solutions indicating the existence of only one ionization step which is the ionization of $-\mathrm{OH}$ or $-\mathrm{COOH}$ groups. The variation of absorbance with $\mathrm{pH}$ is used for the calculation of ionization constants $\left(\mathrm{pK}_{\mathrm{a}}\right.$ values) of 
the investigated ligands using the half height method [20]. The results obtained are of the same order compared to those obtained potentiometrically and are 3.98 , $4.08,7.67,7.98,3.40$ and 3.64 for the investigated ligands (L1-L6), respectively. The ionization of strong acidic carboxylic group is ionized at lower $\mathrm{pH}$ value, due to the high stability of the corresponding anion by resonance. They do not impart any spectral changes as the ionizable proton is not conjugated with the $\pi$-system of the molecule.

\subsection{Determination of the Stoichiometry of the Complexes Spectrophotometrically}

The mole ratio of the metal ions to the ligands was studied spectrophotometrically using molar ratio and continuous variation methods. The spectrophotometric method was used to confirm the data obtained by conductimetric method. UV absorption spectra can be used to determine stoichiometry of the complexes, and this method appears to be valuable for studying complexes with low stabilities.

\subsubsection{Molar Ratio Method}

It was observed that the absorption increases linearly as the ligand concentration increase, because of the formation of the complex until the solution reaches the actual molar ratio of the investigated complex. At this point all of the added materials were completely reacted and the absorption observed is the absorption of the investigated complex alone. After this point, the excess amount of the added ligand causes an inflection in the straight line that is because the ligand has an absorption value differ from that of the complex at $\lambda_{\max }$ of the complex [21]. [L]/[M] ratio corresponding to the inflection point in (Abs$[\mathrm{L}] /[\mathrm{M}]$ curve) indicates to the actual $[\mathrm{L}] /[\mathrm{M}]$ ratio of the investigated complex. It was found that all of the complexes in this investigation are able to be stable in the form $\mathrm{ML}_{2}$.

\subsubsection{Continuous Variation Method}

This method was used to confirm the data obtained using molar ratio and conductivity methods. In this method, The measured absorbance increases as the molar ratio $[\mathrm{M}] /([\mathrm{L}]+[\mathrm{M}])$ increase until the actual molar ratio of the complex is reached, after this point the absorbance becomes lower because the metal has no absorption at $\lambda_{\max }$ of the complex. It was found that all of the curves have inflection points at mole fraction around (0.33); this means that all of the complexes in this investigation have the form $\mathrm{ML}_{2}$ and this form is the most stable form.

\section{CONCLUSIONS}

The results obtained from the potentiometric measure- ments for proton-ligand systems $\left(\mathrm{pK}_{\mathrm{a}}\right.$ values) were 3.98, $4.04,7.68,7.93,3.45$ and 3.66 for the investigated ligands L1-L6, respectively. It is observed that as $\mathrm{pK}_{\mathrm{a}}$ of the ligand increases, the stability constant $\log \beta$ of the complex increase. The stability constants of the metal ions $\left(\mathrm{VO}^{2+}, \mathrm{Cr}^{3+}, \mathrm{Mn}^{2+}, \mathrm{Co}^{2+}, \mathrm{Ni}^{2+}, \mathrm{Cu}^{2+}\right.$ and $\left.\mathrm{Zn}^{2+}\right)$ complexes with the investigated ligands (L1-L6) were found to decrease with increasing ionic strength of the medium which was in agreement with the Debye-Hückel equation. The thermodynamic stability constants $\left(\log \beta^{\circ}\right)$ were obtained by extrapolating the straight line plots of $\log \beta$ versus $\sqrt{\mathrm{I}}$ to zero ionic strength. Also the values of $\mathrm{pK}_{\mathrm{a}}$ were found to decrease with increasing ionic strength of the medium. The values of the thermodynamic functions $\Delta \mathrm{G}, \Delta \mathrm{H}$ and $\Delta \mathrm{S}$ were calculated. The values of stability constants reveal that the stability constants decrease with increasing temperature, along with the $\mathrm{pK}_{\mathrm{a}}$ value. Conductimetric measurements show the presence of two distinctive breaks at metal to ligand molar rations of 1:1 and 1:2, respectively. The results obtained from the spectrophotometric measurements are of the same order compared to those obtained potentiometrically and are $3.98,4.08,7.67,7.98,3.40$ and 3.64 for the investigated ligands (L1-L6), respectively. The ionization of strong acidic carboxylic group is ionized at lower $\mathrm{pH}$ value due to the high stability of the corresponding anion by resonance. They do not impart any spectral changes as the ionizable proton is not conjugated with the $\pi$-system. The mole ratio of the metal ions to the ligands was studied spectrophotometrically using molar ratio and continuous variation methods. All the investigated complexes are found to be stable in the form ML2, which is also the most stable one.

\section{REFERENCES}

[1] Wisniewski, M.Z. (1997) Pd(II) complexes with some derivatives of pyrazol-5-one. Polish Journal of Chemistry, 71(2), 259-260.

[2] Lu, J., Zhang, L., Liu, L., Liu, G., Jia, D., Wu, D. and Xu, G. (2008) Study of fluorescence properties of several 4-acyl pyrazolone derivatives and their $\mathrm{Zn}(\mathrm{II})$ complexes. Spectrochimica Acta Part A, 71(3), 1036-1041.

[3] Kuncheria, B. and Indrasenan, P. (1988) Thorium (IV) nitrate complexes with some substituted pyrazole-5-ones. Indian Journal of Chemistry, 27A, 1005-1007.

[4] Vogel, I. (1978) A text book of practical organic chemistry. 4th Edition, Longman, London.

[5] Tantawy, F., Goda, F. and Abdelal, A.M. (1995) Synthesis and characterization of certain new 3-methyl-4-(substituted phenylazo) isoxazol-5-ones and 3-methyl-4(substituted phenylazo)-pyrazole-5-ones as potential antibacterial agents. The Chinese Pharmaceutical Journal, 47(1), 37-45. 
[6] Rao, S. and Mittra, A.S. (1978) Synthesis and fungitoxicity of 1-phenyl-3-methyl-4-mono arylidene-2-pyrazolin5-thione. Journal of the Indian Chemical Society, 55(7), 745-746.

[7] Fitton, A.O. and Smalley, R.K. (1968) Practical heterocyclic chemistry. Academic Press, London and New York.

[8] Karci, F. and Ertan, N. (2002) Hetarylazo disperse dyes derived from 3-methyl-1-(3', 5'-dipiperidino-s-triazinyl)5-pyrazolone as coupling component. Dyes and Pigments, 55(2-3), 99-108.

[9] Ibrahim, S.A., El-Gahami, M.A., Khafagi, Z.A. and El-Gyar, S.A. (1991) Structure and antimicrobial activity of some new azopyrazolone chelates of $\mathrm{Ni}$ (II) and $\mathrm{Cu}$ (II) acetates, sulfates and nitrates. Journal of Inorganic Biochemistry, 43(1), 1-7.

[10] Abdel-Latif, S.A. (2001) Synthesis and characterization of some 3-phenyl-4-arylazo-5-pyrazolones with $\mathrm{La}$ (III), $\mathrm{Ce}(\mathrm{III}), \mathrm{Th}(\mathrm{IV})$ and $\mathrm{UO}_{2}(\mathrm{VI})$ complexes. Synthesis and Reactivity in Inorganic, Metal-Organic and Chemistry, 31(8), 1355-1374.

[11] Abdel-Latif, S.A. and Hassib, H.B. (2002) Studies of $\mathrm{Mn}(\mathrm{II}), \mathrm{Co}(\mathrm{II}), \mathrm{Ni}(\mathrm{II})$ and $\mathrm{Cu}(\mathrm{II})$ Chelates with 3Phenyl-4-(p-methoxyphenylazo)-5-pyrazolone. Journal of Thermal Analysis and Calorimetry, 68(3), 983-995.

[12] Hassib, H.B. and Abdel-Latif, S.A. (2003) Potentiometric, spectrometric thermal and conductimetric studies on some 3-phenyl-4-(arylazo)-5-pyrazolones and their complexes with divalent cobalt metal ion. Spectrochimica Acta Part A, 59(11), 2425-2434.

[13] Sarin, R. and Munshi, K.N. (1972) Thermodynamics of complex formation of indium metal ion with mercapto hydroxyl and amino substituted succinic acid. Journal of Inorganic and Nuclear Chemistry, 34(2), 581-590.

[14] Britton, H.T.S. (1952) Hydrogen ions. 2nd Edition, Chapman and Hall, London.

[15] West, T.S. (1969) Complexemetry with EDTA and related reagents. 3rd Edition, B. D. H. Chemical Ltd Poole, London.

[16] Vogel, I. (1956) Practical organic chemistry including quantitative organic analysis. 3rd Edition, Longmans, London.

[17] Irving, H. and Rossotti, H.S. (1953) Methods for computing successive stability constants from experimental formation curves. Journal of Chemical Society, 33973405.
[18] Zumdal, S.S. (1997) Chemistry. 4th Edition, Houghton Mifflin Company.

[19] Vogel, A.I. (1956) Practical organic chemistry including quantitative organic analysis. 3rd Edition, Longmans, London.

[20] Issa, Y.M., Abdel-Ghani, N.T. and Abdel-Latif, S.A. (1996) Spectrophotometric studies on some hydroxy nitrocoumarins. Egyptian Journal of Chemistry, 39(3), 235-248.

[21] Bauer, H.H., Christian, G.D. and O'Reilly, J.E. (1978) Instrumental analysis. Allyn and Bacon Inc.

[22] McMurry, J. (2000) Organic chemistry. 5th Edition, Brooks/Cole, USA.

[23] Schwarzenbach, G. and Flaschk, H. (1969) Complexometric titrations. Methuen and Co. Ltd., London.

[24] Moeller, T., Martin, D.F., Thompson, L.C., Ferrus, R., Feistel, G.R. and Randal, W.J. (1965) The coordination chemistry of yttrium and the rare earth metal ions. Chemical Reviews, 65(1), 1-50.

[25] Gutmann, K. (1966) Conductimetric titration of charge transfer complexes in solution. Electrochimica Acta, 11(6), 555-568.

[26] Singh, P. and Ojha, A.C. (1980) Synthesis of N-isonictinyl-3-methyl-4-(substituted-hydrazono)-2-pyrazolin-5one. Journal of the Indian Chemical Society, 57(12), 1172-1173.

[27] Snavely, F.A. and Krecker, B.D. (1959) Metal derivatives of arylazopyrazolone dyes III, molarity quotients of paraand meta-substituted pyrazolone dyes. Journal of the American Chemical Society, 81(16), 4199-4200.

[28] William, W.P. (1993) Inorganic chemistry. 2nd Edition, Academic Press Inc.

[29] Manku, G.S., Gupta, R.D., Bhat, A.N. and Jain, B.D. (1968) Determination of the stability constants of some lanthanon complexes with 1-nitroso-2-naphthol, 2-nitroso-1-naphthol, and 3-nitroso-4-hydroxycoumarin. Journal of the Less Common Metals, 16(4), 343-350.

[30] Debye, P. and Hückel, E. (1923) Physik. Z., 24, 185-206.

[31] Saxena, R.S. and Gupta, A. (1984) Potentiometric determination of dissociation constants of dithiodipropionic acid in different media. Journal of the Electrochemical Society India, 33(1), 89-90.

[32] Yadav, S.S. and Saxena, R.S. (2009) Formation constants and thermodynamic parameters of some tri-ligand complexes of lanthanides. Journal of the Indian Chemical Society, 86(2), 168-170. 